\title{
Cognitive and non-cognitive determinants of academic and life success
}

\author{
Aleksander I. Savenkov ${ }^{1 *}$ \\ ${ }^{1}$ Moscow City University, Institute of Pedagogy and Psychology of Education Psychological \\ Sciences, Moscow, Russia
}

\begin{abstract}
The article is devoted to the problems of association between academic and life success of a person with the levels of their cognitive development and several non-cognitive factors. Not only at the level of implicit theories that typically serve as a basis for educational practice but also in specialized psychological works, giftedness is often defined through success, although it is impossible not to recognize these phenomena as fundamentally different. In this regard, providing a distinction between the concepts of "giftedness" and "success" (both academic and life success) appears to be a relevant objective. The main proposition in the present article is that most specialists studying giftedness as personality potential view cognitive factors, primarily intellect and creativity (less often other cognitive functions), as its core and at the rare instances that the non-cognitive factors are considered, they are examined not in association with the structure of giftedness but merely as predictors of success. Therefore, the objective of examining and classifying the cognitive and non-cognitive factors of giftedness development, as well as autonomously analyzing the effective determinants of academic and life success of a person appears to be important and significantly novel. The present article has the nature of a theoretical review, therefore, the research method deployed in it is the analysis of theoretical sources across the broadest possible time frame. Consideration of the evolution of ideas of researchers from different countries and eras and the projection of their judgments, conclusions, and recommendations onto educational and social practice can shed light on the modern understanding of these processes both in scientific and everyday psychology.
\end{abstract}

Keywords: cognitive factors, non-cognitive factors, intelligence, creativity; giftedness; academic success; life success.

\section{Introduction}

From the formal point of view, it is quite logical to assume that giftedness in general and childhood giftedness, in particular, have to be considered as personality potential allowing an individual to achieve high results in learning (academic success) and further life (existential success). The practice of school education and biographies of former "prodigies"

\footnotetext{
* Corresponding author: asavenkov@bk.ru
} 
show that this is not always the case. Children and adults viewed by psychologists as gifted are often unsuccessful both at the stage of school education and in adulthood [1-4].

The "giftedness/non-giftedness" line shapes the border between the understanding of giftedness and attitude towards it on the part of researchers in psychology and society in general including teachers. Psychology is interested in giftedness as personality potential while teachers and society are concerned with a person's actual achievements in education and practice. Therefore, children that are considered gifted by psychologists are those who demonstrate high results in the assessment of intelligence, creativity, and several noncognitive characteristics. Meanwhile, teachers, without a shadow of a doubt, view gifted children as those that are successful in school, as well as winners of Olympiads, competitions, and various contests although, strictly speaking, these are simply successful children whose success may be due to various factors that have little to do with giftedness. The same vision is present in society regarding successful adults. People who have achieved success in a certain activity are unequivocally declared gifted, even though they are only successful it remains unknown whether they are, in fact, gifted. The outlined inconsistencies in the understanding of the meaning of "giftedness" are major and have a long history but remain unrecognized by many as a serious problem.

In this context, distinguishing the concepts of "giftedness" and "success" (both academic and life success) appears to be a relevant task. The main proposition of the present work is that most specialists who view giftedness as personality potential consider cognitive factors, primarily intellect and creativity (less often other cognitive functions), as its core and at the rare instances that the non-cognitive factors are mentioned, they are examined not in association with the structure of giftedness but merely as predictors of success. Therefore, it appears to be an important and largely novel objective to examine and classify the cognitive and non-cognitive factors of the development of giftedness and conduct an autonomous analysis of effective determinants of academic and life success of a person.

\section{Methods}

Since the present article essentially presents a theoretical review, the main instrument deployed in it is the analysis of theoretical sources across the broadest possible time frame. Consideration of the evolution of ideas of researchers from different countries and eras and the projection of their judgments, conclusions, and recommendations onto educational and social practice can correct the modern understanding of these processes both in scientific and everyday psychology.

\section{Results}

The philosophers of the first European civilizations clearly outlined the spheres of life and activity in which a person's gift can be realized. The term "giftedness" was not used in those distant days; philosophers used the term "genius". Aristotle was one of the first to offer a classification of the efforts of genius. He divided the spheres of human genius into "contemplative activity of mind" (artistic and scientific) and "virtuous" or practical (state administration, military affairs, trade, etc.). He also pointed out that true genius can manifest itself only in art. Aristotle believed that there can be no geniuses in science (what a scientist discovers shortly becomes available to their students), much less in the sphere of practical activity. This view of high achievement dominated European consciousness until the end of the 19th century. At the turn of the 19th and 20th centuries, there formed an understanding that the main place of application of the forces of genius was science, and it was only at the 
end of the 20th century that the civilizational ideas about the scope of genius efforts shifted to the sphere of practical activity.

Be that as it may, interest in the factors and especially the predictors of high achievement has been consistently high at all times. Therefore, the descriptions of predictive scenarios and reasons for high achievements can be found since the times of the first European civilizations. While philosophers of Ancient Greece considered the "divine conduction" as such reason, the establishment of scientific psychology as an independent field of knowledge entailed the consideration of a complex combination of two large groups of factors: environmental and genotypic. Subsequently, there began a discussion of the influence of another dichotomy: cognitive/non-cognitive determinants.

Surprisingly, even in our time, the understanding of "giftedness" and "success" as synonymous concepts has penetrated even into scientific psychology. For example, in the work of Russian scientists entitled "The Working Concept of Giftedness", the concepts of "giftedness" and "gifted child" are defined by the authors through success [5]. A similar interpretation of the concepts of a "gifted child" and "giftedness" in general is found in many other publications of Russian and foreign authors [6].

In the early 20th century, thanks to the developments of French psychologists working under A. Binet, as well as the formula for calculating IQ (intelligence quotient) proposed by the German psychologist W. Stern, practitioners working in education received what then seemed to be a convenient tool for differentiating children in learning. Similarly, human resources personnel working in a wide variety of industries thought that they had found a convenient and mobile tool for determining the degree of perspective of apprentices and employees. The fallacy of these expectations became apparent shortly. Already in the first decades of mass testing with different variants of IQ tests, it became clear that intelligence detected in this way does not always guarantee success in schooling and correlates much less with success in life.

By the middle of the 20th century, these circumstances led researchers to consider creativity as the main predictor of personal success. The first studies already showed that creativity correlates very poorly with academic success but theoretically has to have a high correlation with life success $[7,8]$. The need to consider giftedness through the prism of success dictated by society has led to the fact that the main indicated characteristics of the cognitive sphere of personality (intellect and creativity) naturally started to include the features of an individual's psychosocial development.

Modern psychology predominantly follows the notion that giftedness should be viewed as a combination of three basic characteristics: intelligence, creativity, and motivation [9]. Despite the endless attempts of different authors to propose their own versions of the concept of giftedness, it is easily noticeable that the triad proposed by J. Renzulli remains at the core of all the proposed models The difference is only observed in the description of the dominant factors of its development.

Studies of general and particular (special) giftedness as predictors of academic and life success have led researchers to interesting and even unexpected results. An American psychologist J. Stanley who compared the contribution of general cognitive factors (intelligence and creativity) and high mathematical ability in his longitudinal studies found that children who scored high on the SAT math section tend to be more successful both in school and in life. Initially, he began to work on the "The Study of Mathematically Precocious Youth" that had been transformed into "The Study of Exceptional Abilities" program by the 1980s. Using a sample of several hundred subjects surveyed over forty-five years, Stanley found that maximum scores on the mathematics section of the SAT had a higher predictive value than the universally accepted tests of intelligence or creativity [10]. Stanley's line of research is currently continued by a similar research program at the Johns 
Hopkins Institute. It examines the influence of special mathematical giftedness on academic and life success.

In the context of our examination, of critical importance is the "intelligence range model" proposed by D. Perkins and further developed by V.N. Druzhinin. D. Perkins' idea of the presence of an "intellectual threshold" in any kind of activity can be represented and considered as the idea of having a general "cognitive threshold" that can be determined by tests of intelligence, creativity, and other cognitive abilities including special mathematical abilities. The idea that there is a "cognitive threshold" determining the degree of success in performing an activity emphasizes the importance of understanding that when a person conditionally passes this threshold, high achievement is determined by non-cognitive factors (will, character, etc.) rather than a maximum level of cognitive development.

While a relatively unified understanding is present among researchers regarding the classification of cognitive predictors of academic and life success [11], the list of proposed non-cognitive factors significantly varies. Some researchers consider the "big five" as noncognitive factors which is certainly quite logical [12]. However, allowing for the possibility of such a solution, one cannot but notice that many other non-cognitive factors are influencing the academic and life success of an individual.

V.S. Iurkevich, a Russian psychologist specializing in the study of children's giftedness, has repeatedly noted in her works based on many years of research that most gifted children identified through intelligence and creativity tests are characterized by emotional immaturity, infantilism, and relatively low interest in everything unrelated to cognitive activity. Her main conclusion is that the higher the child's level of cognitive development, the more likely they are to have difficulty establishing social contacts with peers and adults [13].

A separate group of studies is formed by research on the influence of such factors as social intelligence and emotional intelligence on academic and life success [14-17]. The importance of the factors of emotional intelligence and social competence of an individual in achieving life success is rated highly by modern futurologists [18]. Israeli psychologist R. Bar-On argues that both the academic and life success of an individual is ensured by such qualities as self-awareness, communication skills, the ability to adapt, the ability to manage stressful situations, and predominantly good mood [14].

\section{Discussion}

The specialized study and classification of cognitive and non-cognitive determinants of academic and life success of a person continue. Increased attention of researchers in humanitarian sciences has recently been drawn by the results of retrospective analysis of the dynamic of the development of intelligence as one of the key cognitive characteristics. While in the 1980s, a New Zealand political scientist J. Flynn found that intelligence scores had been increasing significantly in most of the world from the beginning to the end of the 20th century [19], several contemporary researchers argue that we are facing a decline in the early decades of the 21 st century [20].

Psychologists discuss this matter with much caution due to the lack of sufficient empirical data. In contrast, cultural scientists, political scientists, sociologists, educators, and mainly journalists, probably based on their impressions of the functioning of educational systems, speak not only of a decline in the level of knowledge but also of the allegedly observed cognitive degradation of modern youth. The widespread use of information technology is cited as the main reason for this degradation. It has been argued that the more money mankind invests in information resources, the lower the academic achievement of students at all levels of education, and the more time schoolchildren and students work with information resources, the more intensively they degrade cognitively [21]. However, these conclusions are made on insufficiently reliable grounds and need to be researched. 


\section{Conclusion}

The study of childhood giftedness as a complex combination of cognitive and non-cognitive factors factually presents the study of personality potential that can lead to academic and even life success, although it is not a hundred percent guarantee. The problems of academic and life success of an individual should be studied autonomously since they depend not only on personality characteristics studied by psychology but also on social and even incidental factors.

\section{References}

1. T.I. Lubart, H. Holling, D.V. Ushakov, Learning and Individual Differences, 52, 120 (2016)

2. A.I. Savenkov, S.I. Karpova, E.I. Sukhova, Psychology (Savannah, Ga.), 55(2), 74-84 (2018)

3. N.B. Shumakova, Paradoksy akademicheskoi uspeshnosti mladshikh shkolnikov [Paradoxes of academic success in younger schoolchildren], in A.L. Zhuravlev (Ed.), Sposobnosti i mentalnye resursy cheloveka v mire globalnykh peremen [Human abilities and mental resources in the world of global changes], 662-669 (Institute of Psychology RAS, Moscow, 2020)

4. E.I. Shcheblanova, EpSBS, 64, 627-633 (2019). https://doi.org/10.15405/epsbs.2019.07.82

5. B.D. Bogoiavlenskaia, et al. (Eds.), Rabochaia kontseptsiia odarennosti [The working concept of giftedness] (Ministry of Education of the Russian Federation, Moscow, 2003)

6. G. Trost, Inostrannaia Psikhologiia, 11, 19-29 (1999)

7. J.P. Guilford, The nature of human intelligence (McGraw-Hill, New York, 1967)

8. E.P. Torrance, T. y Wu, Creative Child and Adult. Quarterly, 6, 71-76 (1981)

9. J. Renzulli, S.M. Reis, Model obogashchennogo shkolnogo obucheniia: prakticheskaia programma stimulirovaniia odarennykh detei [The model of enriched school learning: a practical program of stimulating gifted children], in B.D. Bogoiavlenskaia (Ed.), Sovremennye kontseptsii odarennosti i tvorchestva [Modern concepts of giftedness and creativity] (Molodaya gvardiya, Moscow, 1997)

10. J. Stanley, The Journal of Creative Behavior, 31(2), 93-119 (1997). https://doi.org/10.1002/j.2162-6057.1997.tb00783.x

11. L.A. Verbitskaya, Yu.P. Zinchenko, S.B. Malykh, I.V. Gaidamashko, O.A. Kalmyk, T.N. Tikhomirova, Psychology in Russia: State of the Art, 13(2), 2-15 (2020)

12. Iu.A. Ishmuratova, V.I. Morosanova, A.M. Potanin, V.A. Tsyganov, Bulletin of Moscow State Region University. Series - "psychological sciences", 3, 25-40 (2019)

13. V.S. Iurkevich, Journal of Modern Foreign Psychology, 7(2), 28-38 (2018). https://doi.org/10.17759/jmfp.2018070203

14. R. Bar-On, Emotional intelligence and self-actualization, in J. Ciarrochi, J. Forgas, J. D. Mayer (Eds.), Emotional intelligence in everyday life: A scientific inquiry, 82-97 (Psychology Press, New York, 2001)

15. J.D. Mayer, P. Salovey, Electronic Journal of Research in Educational Psychology, 15(6(2)), 421-436 (2008) 
16. A.I. Savenkov, Journal of Modern Foreign Psychology, 7(2), 7-15 (2018). https://doi.org/10.17759/jmfp.2018070201

17. T.D. Savenkova, Razvitie sotsialnogo intellekta doshkolnikov [The development of social intelligence in preschool children] (Iurait, Moscow, 2020)

18. M. Kaku, Budushchee razuma [The future of mind] (Alpina Non-fiction, Moscow, 2015)

19. J.R. Flynn, Psychological Bulletin, 95(1), 29-51 (1984). https://doi.org/10.1037/00332909.95.1.29

20. T.W. Teasdale, D.R. Owen, Personality and Individual Differences, 39(4), 837-843 (2005). https://doi.org/10.1016/j.paid.2005.01.029.

21. M. Spitzer, Antimozg: tsifrovye tekhnologii i mozg [The anti-brain: digital technology and the brain] (AST, Moscow, 2014) 